Received 06.02.2015 Reviewed 20.05.2015 Accepted 02.06.2015

A - study design

B - data collection

C - statistical analysis

D - data interpretation

E - manuscript preparation

F - literature search

\section{A methodology for flood risk appraisal in Lithuania}

\author{
Irena KRIŠČIUKAITIENE் ${ }^{\mathrm{AE}}$, Tomas BALEŽENTIS ${ }^{\mathrm{ABCE}}$, \\ Aistė GALNAITYTÉ ${ }^{\text {ABEF }}$, Virginia NAMIOTKO ${ }^{\text {ABEF }}$
}

Lithuanian Institute of Agrarian Economics, V. Kudirkos Str. 18-2, 03105 Vilnius, Lithuania; e-mail: irena@laei.lt

For citation: Kriščiukaitienė I., Baležentis T., Galnaitytė A., Namiotko V. 2015. A methodology for flood risk appraisal in Lithuania. Journal of Water and Land Development. No. 25 p. 13-22

\begin{abstract}
This paper presents a methodology for flood risk mapping as envisaged by the Directive on the Assessment and Management of Flood Risks [Directive 2007/60/EC]. Specifically, we aimed at identifying the types of flood damage that can be estimated given data availability in Lithuania. Furthermore, we present the main sources of data and the associated cost functions. The methodology covers the following main types of flood threats: risk to inhabitants, risk to economic activity, and social risk. A multi-criteria framework for aggregation of different risks is proposed to provide a comprehensive appraisal of flood risk. On the basis of the proposed research, flood risk maps have been prepared for Lithuania. These maps are available for each type of flood risk (i.e. inhabitants, economic losses, social risk) as well as for aggregate risk. The results indicate that flood risk management is crucial for western and central Lithuania, whereas other parts of the country are not likely to suffer from significant losses due to flooding.
\end{abstract}

Key words: flood map, flood probability, flood risk, Lithuania

\section{INTRODUCTION}

Estimation of flood damages is of importance due to several reasons. First, floods are acknowledged as one the most common emergencies. Second, knowledge on the scale and type of damage allows the adequate preventive measures to be chosen in advance. Third, with the clear perception of potential losses effective solutions are adopted as regards structural (requiring considerable investment) changes. In addition, the consequences of climate change are likely to be associated with an increasing risk of flooding [EEA 2012]. In the light of the aforementioned findings, a directive on flood risk management has come into force across the European Union [Directive 2007/60/EC]. Pursuant to the directive, each Member State of the European Union must adopt appropriate plans regarding flood risk management. These ac- tions, indeed, marked a new approach regarding flood risk mitigation [HARTMANN, ALBRECHT 2014].

The objective of flood risk management is to quantify flood risk and thus identify the loci associated with the highest risk to envisage risk prevention measures. Flood maps constitute one of the core components of the flood risk management. Therefore, various instances of flood maps emerged in different European countries [JONKMAN 2008; MESSNER et al. 2007; MoEL et al. 2009]. Anyway, there are a number of manifestations of suchlike analyses in other regions

of the world [MIDDELMANN-FERNANDES 2010; OU-

MA, TATEISHI 2014; WeBSTER 2014]. The key concepts related to flood risk have been discussed by GOULDBY and SAMUELS [2005]. 
When evaluating flood risk, flood probability and flood damage is considered [GOULDBY, SAMUELS 2005]. Whereas flood probability is associated with the likelihood of the occurrence of certain flooding events, the term "flood damage" refers to adverse consequences caused by floods to people, human health and property, public infrastructure, cultural heritage, landscape, industrial production and competitive capacity of affected economies.

This paper presents the methodology for estimation of flood risk in Lithuania, which was prepared according to EU Directive on the Assessment and Management of Flood Risks [Directive 2007/60/EC]. The proposed risk estimation methodology allows the construction of flood risk maps.

The paper proceeds as follows: Section 2 presents the preliminaries for flood risk mapping in Lithuania, viz. data sources and risk types analysed. Section 3 presents the methodology for estimation of different risk types. Section 4 presents the risk maps based on the proposed methodology.

\section{DATA SOURCES AND METHODOLOGICAL FRAMEWORK FOR FLOOD RISK MAPPING}

Information on the amount and type of property in the risk zone is usually based on the land use data. The data may be primary, obtained by way of questionnaires, and secondary - retrieved from the dedicated databases (such as CORINE Land Cover data). In certain countries, cadastre maps, national real estate data etc. may be available for researchers. Additional data may be received from market research databases, where one can find information on the population number, buildings, specific features of buildings, apartments, age, social status, the purchasing power of people, the number of enterprises and direction of their activity, the number of workers [MESSNER et al. 2007].

National accounts contain data on the gross and net value of fixed assets at market prices. This indicator covers residential and non-residential buildings, facilities, thus it characterizes the total property. Nevertheless, this indicator does not encompass inventories and household goods. This information should be obtained from other sources.

Asset value per square metre across separate type of assets may be also modelled, with the modelling results being corrected using the marketing research data. Moreover, asset values by land use categories may be approximated from these results. Data for detailed research should be based on the consolidated reports on real estate market prices and construction cost directories. Inventories and household goods may be estimated by the method of expert evaluation and based on the sources of different statistical information. Inventories and household goods may be estimated at their actual value. Household goods may be estimated by using data of insurance companies or data on household expenses for such goods. Inventory and stock value of enterprises by type of activity may be found in some statistical yearbooks. Market value is often used as a basis for estimation of the vehicle value, which is then adjusted by the linear depreciation method according to the average age of the national car fleet. For estimation of road and railroad value, their construction tariffs are used [MESSNER et al. 2007]. The discussed methods, however, cannot be used for determining the total (gross) value of a hazard as they should be integrated into damage functions.

In the sense of requirements of the EU directive [Directive 2007/60/EC], flood risk assessment methodologies in the European countries and data availability in Lithuania, the following three categories of flood damage are further considered:

1) risk to inhabitants,

2) risk to economy and environment,

3) risk associated to socio-political aspects.

Separate flood risk maps would be prepared for each above-mentioned category of impact, since the results are expressed in different dimensions. The data from three flood risk maps will be used in preparing an integrated flood risk map, depicting the overall flood risk.

Risk to inhabitants is estimated by considering the sole indicator, viz. the number of people residing in the inundation area. Therefore, additional methods are not applied for this type of risk. Economic flood damage is evaluated in terms of indicators expressed in monetary units. In the latter case, flood damage functions relating flood characteristics to a degree of hazard on a certain type of assets, i.e. a share of asset value, are applied. In assessment of social damage, it is necessary to aggregate the flood damage characterizing indicators which are expressed in different measurement units.

When making the integrated flood risk map, all types of damage are integrated and evaluated for each grid of the map. For that purpose, multi-criteria evaluation methods are applied. Generally, the three levels of flood probability are considered, namely $0.1 \%, 1 \%$, and $10 \%$.

\section{ESTIMATING DIFFERENT TYPES OF RISK}

\section{RISK TO INHABITANTS}

The number of residents that may be affected in the event of flood is estimated using the geographic data of the 2011 population census. Statistics Lithuania possesses spatial data (address points with the number of inhabitants as reported during the population census), though strict confidential requirements are applied in respect of these data. The number of inhabitants that may be affected in the event of flood is related to a cell of different size in a map: in city municipalities - a cell size $100 \mathrm{~m} \times 100 \mathrm{~m}$; in cities a cell size $250 \mathrm{~m} \times 250 \mathrm{~m}$; in other territories - a cell size $1000 \mathrm{~m} \times 1000 \mathrm{~m}$. 
Statistics Lithuania, based on a geographic query (polygons of inundated territories under different flooding probabilities), would collect data on the number of inhabitants affected and aggregate these data for the cells of the above-indicated sizes. Polygons for a geographic query would be formed by disregarding islands, i.e. it is assumed that residents in both water inundated areas and in flood separated zones (islands) suffer equally.

The number of inhabitants that may be affected in the event of flood may be displayed in a flood risk map at the precision of a single unit (the value of a cell might be, e.g., 32 residents) or at intervals (the value of a cell might be, e.g., 25-50 residents). Number may be presented at the precision of a single unit only if more than 10 inhabitants are associated to a cell. If a cell contains more than zero but less than 10 residents, the value of $<10$ inhabitants is shown.

\section{RISK TO ECONOMIC ACTIVITIES AND ENVIRONMENT}

Flood damage to economic activities and environment is estimated via respective damage functions and GIS data on real estate objects. In this risk category, we analyse various types of objects (Tab. 1).

Table 1. Types of flood damage to economic activities and environment

\begin{tabular}{|l|l|}
\hline \multicolumn{1}{|c|}{$\begin{array}{c}\text { Type of economic } \\
\text { damage }\end{array}$} & \multicolumn{1}{|c|}{ Calculation of possible flood losses } \\
\hline $\begin{array}{l}\text { Restoration costs of } \\
\text { buildings }\end{array}$ & $\begin{array}{l}\text { Flood damage to buildings is assessed in } \\
\text { terms of construction value (real estate } \\
\text { replacement costs) and inundation depth. } \\
\text { Construction value is differentiated by } \\
\text { building purpose (residential buildings, } \\
\text { production premises, farm outbuildings) } \\
\text { and residential area (urban, rural) }\end{array}$ \\
\hline $\begin{array}{l}\text { Repair costs of infra- } \\
\text { structure objects }\end{array}$ & $\begin{array}{l}\text { Repair costs of infrastructure objects are } \\
\text { based on construction costs and inunda- } \\
\text { tion depth. Construction cost of an infra- } \\
\text { structure object varies depending on the } \\
\text { road purpose (roads of national signifi- } \\
\text { cance, roads of local significance, urban } \\
\text { roads (streets)) }\end{array}$ \\
\hline $\begin{array}{l}\text { Losses of agricultural } \\
\text { biological assets }\end{array}$ & $\begin{array}{l}\text { Losses of agricultural biological assets are } \\
\text { based on crop farming and animal farming } \\
\text { losses. Damage to crop farming is as- } \\
\text { sessed according to the crop output value } \\
\text { in favoured areas (FA) and less favoured } \\
\text { areas (LFA). Animal farming losses are } \\
\text { proportional to the number of residents at } \\
\text { flood risk }\end{array}$ \\
\hline $\begin{array}{l}\text { Indirect economic, } \\
\text { social costs and ex- } \\
\text { penses with emergency }\end{array}$ & $\begin{array}{l}\text { Losses are estimated based on construc- } \\
\text { tion prices of respective infrastructure } \\
\text { objects and inundation depth. The same } \\
\text { damage function is used as for infrastruc- } \\
\text { ture objects }\end{array}$ \\
\hline $\begin{array}{l}\text { Losses due to interrup- } \\
\text { tion in economic ac- } \\
\text { tivities }\end{array}$ & $\begin{array}{l}\text { Losses due to interruption in the economic } \\
\text { activities in urban and rural areas are es- } \\
\text { timated on the basis of the number of } \\
\text { employed people per ha in urban and rural } \\
\text { areas and by Gross Added Value (GAV) } \\
\text { created per working day per worker on the } \\
\text { average in the county }\end{array}$ \\
\hline $15 \%$ of the total direct costs \\
\hline
\end{tabular}

and long-term aid

measures

Source: own elaboration.

\section{Restoration costs of buildings}

Costs associated with restoration of buildings affected by flooding are estimated on the basis of Lithuanian geo-reference databases (polygons of buildings) and flood hazard map data (under $10 \%, 1 \%$ and $0.1 \%$ probability polygons of inundated territories and water depth grid). The detailed information regarding data sources is presented in Table 2 .

Table 2. Data and their sources when calculating flood damage to buildings

\begin{tabular}{|l|l|}
\hline \multicolumn{1}{|c|}{ Data } & \multicolumn{1}{c|}{ Data sources } \\
\hline $\begin{array}{l}\text { Residential buildings } \\
\text { Industrial buildings } \\
\text { Outbuildings and buildings } \\
\text { of other (farm) purposes }\end{array}$ & $\begin{array}{l}\text { LR Real Estate Cadastre and LR Real } \\
\text { Estate Register data M 1:10 000 on } \\
\text { buildings } \\
\text { Lithuanian geo-reference database } \\
\text { GDB10LT, maps.lt data }\end{array}$ \\
\hline Construction costs & $\begin{array}{l}\text { Order of State Enterprise Centre of } \\
\text { Registers "Regarding Determination } \\
\text { of the Mean Value of Construction of } \\
\text { Residential and Non-residential } \\
\text { Buildings from 1 January 2013", 18 } \\
\text { December 2012, No. V-356. }\end{array}$ \\
\hline
\end{tabular}

Source: own elaboration.

Restoration costs of a building are estimated as follows:

$$
R^{b}=\sum_{p \in\{0.001 ; 0.01 ; 0.1\}}(p A(p, \varepsilon) d(h(p)))
$$

where:
$R^{b}$ - restoration cost of a building,
$A(\cdot)$ - the area of a building's foundation de- pendent on flood characteristics,
$V$ - construction cost of the building,
$d(\cdot)$ - the value of a damage function,
$h(\cdot)$ - the inundation depth under a given level of probability.

Figure 1 depicts the damage function used for estimation.

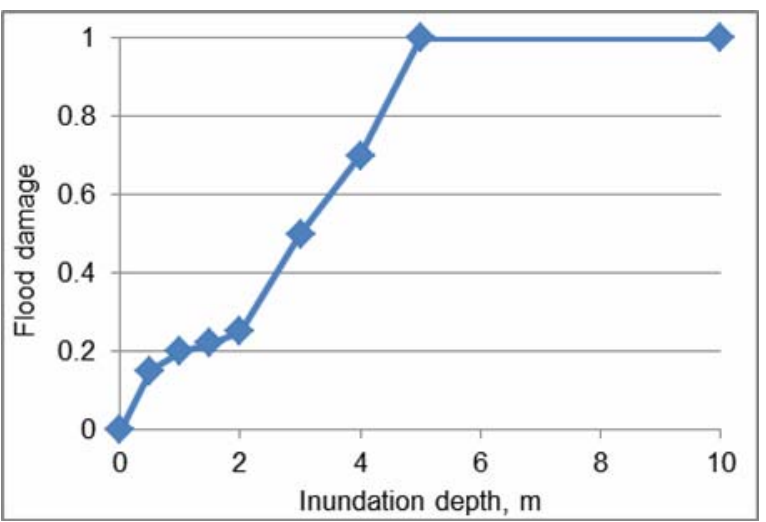

Fig. 1. Damage function for buildings; source: prepared acc. to VAN DER SANDE et al. [2003], MEYER et al. [2011] 
These costs are estimated by considering real estate construction (replacement) prices for the year 2013 for Lithuanian cities and villages, with regard to different construction types and volume of buildings [SISTELA 2012]. Data show that with an assumption that multi-apartment buildings prevail in cities $(60 \%)$, whereas in villages, on the contrary, one- and twoapartment timber and brick, etc. houses are more prevalent, it is possible to take the same mean value of construction cost for both urban and rural areas. Thus the construction (replacement) cost for residential buildings is assumed to equal $570 \mathrm{LTL} \cdot \mathrm{m}^{-3}(165$ EUR $\cdot \mathrm{m}^{-3}$ ). Damage to other buildings is estimated in a similar manner, assuming that constructions costs for production premises are $271 \mathrm{LTL} \cdot \mathrm{m}^{-3} \quad(78$ EUR $\cdot \mathrm{m}^{-3}$ ) and those for farm outbuildings are 255 $\mathrm{LTL} \cdot \mathrm{m}^{-3}\left(73 \mathrm{EUR} \cdot \mathrm{m}^{-3}\right)$.

\section{Repair costs of infrastructure objects}

By the virtue of standard ArcGIS software functions, layers of road (linear) and inundated territories (polygon) are intersected. Using the flood water depth grid data of flood hazard maps, the mean water depth is calculated per inundated road section at $10 \%, 1 \%$ and $0.1 \%$ probability flood.

Assessment of flood damage to infrastructure objects is performed by analyzing the reconstruction cost (Tab. 3).

Table 3. Data and their sources when calculating flood damage to infrastructure objects

\begin{tabular}{|l|l|}
\hline \multicolumn{1}{|c|}{ Indicators } & \multicolumn{1}{|c|}{ Data sources } \\
\hline Roads of national significance & LR Real Estate Cadastre and LR \\
Urban roads & Real Estate Register data M \\
Roads of local significance & $1: 10$ 000 on infrastructure objects \\
Other structures of transport & Lithuanian geo-reference database \\
communications (pavements, & GDB10LT/ maps.lt data \\
pathways, plantations, etc.) & \\
\hline Construction cost & Sistela [2012] \\
\hline
\end{tabular}

Source: own elaboration.

Road restoration costs shall be calculated according to the formula:

$$
R^{r}=V \sum_{p \in\{0.001 ; 0.01 ; 0.1\}}(p L(p, \varepsilon) d(h(p)))
$$

where:

$$
\begin{aligned}
& R^{r}-\text { restoration cost of a road, } \\
& L \quad-\text { the road length, } \\
& V \quad-\text { construction cost of the road, } \\
& d(\cdot)-\text { the value of a damage function, } \\
& h(\cdot)-\text { the inundation depth under a given level } \\
& \quad \text { of probability, } p .
\end{aligned}
$$

Figure 2 depicts the damage function used for estimation of the road damage.

Road repair costs depend on the number of lanes,

\begin{tabular}{|c|c|c|c|}
\hline \multirow[b]{2}{*}{ Purpose } & \multirow[b]{2}{*}{ Characteristics } & \multicolumn{2}{|c|}{ Reconstruction price } \\
\hline & & $\begin{array}{c}\text { thous. } \\
\mathrm{LTL}^{\mathrm{kTm}} \mathrm{km}^{-1}\end{array}$ & $\begin{array}{c}\text { thous. } \\
\text { EUR } \cdot \mathrm{km}^{-1}\end{array}$ \\
\hline \multirow{4}{*}{$\begin{array}{l}\text { Roads of } \\
\text { national } \\
\text { significance }\end{array}$} & category AM (4 traffic lanes) & 10512 & 3044 \\
\hline & category I (4 traffic lanes) & 9552 & 2766 \\
\hline & $\begin{array}{l}\text { categories II-III (2 traffic } \\
\text { lanes) }\end{array}$ & 3386 & 981 \\
\hline & $\begin{array}{l}\text { categories IV-V (2 traffic } \\
\text { lanes) }\end{array}$ & 1283 & 372 \\
\hline \multirow{2}{*}{$\begin{array}{l}\text { Roads of } \\
\text { local sig- } \\
\text { nificance }\end{array}$} & Iv-IIv (asphalt cover) & 508 & 147 \\
\hline & Iv-IIIv (gravel cover) & 168 & 49 \\
\hline \multirow{3}{*}{$\begin{array}{l}\text { Urban roads } \\
\text { (streets) }\end{array}$} & $\begin{array}{l}\text { fast lane or main road (4 } \\
\text { traffic lanes) }\end{array}$ & 4323 & 1252 \\
\hline & servicing (2 traffic lanes) & 1671 & 484 \\
\hline & auxiliary & 949 & 275 \\
\hline
\end{tabular}
road category and cover; however, they are uniform across the administrative regions and types of residential areas. It is assumed that flood-damaged road re- construction costs the construction prices for structures established by Sistela, JSC (Tab. 4).

Table 4. Road reconstruction prices

Source: Sistela [2012], modified.

Damage function for roads is presented in Fig. 2.

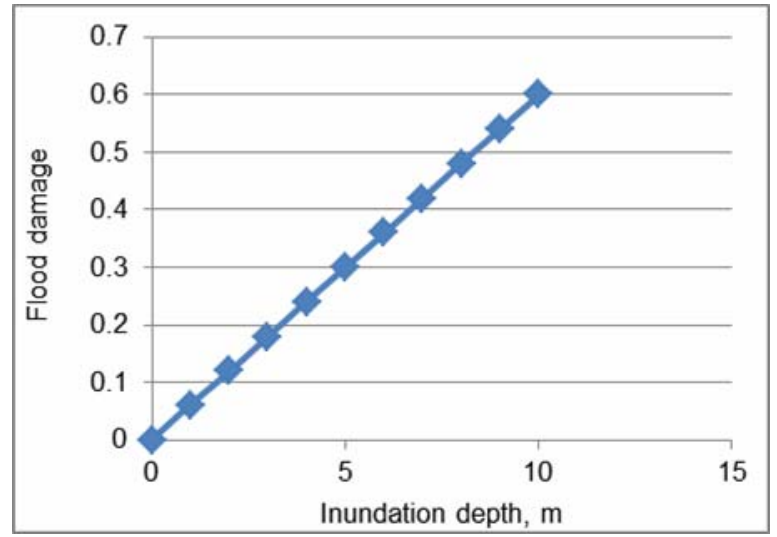

Fig. 2. Damage function for roads; source: prepared acc. to VAN DER SANDE et al. [2003], MEYER et al. [2011]

The infrastructure objects also include car parking sites, pavements, pathways, plantations and access roads. Their reconstruction prices are provided in Table 5 and alike for the roads are equal within the territory of the country as well as in cities and villages. Damage to these objects is calculated in terms of area of objects, reconstruction value (Tab. 5), damage function (the same function is used as in case of road damage, cf. Fig. 2) and flood probability.

Table 5. Reconstruction prices for other infrastructure objects

\begin{tabular}{|l|l|c|c|}
\hline \multirow{2}{*}{ Purpose } & \multicolumn{2}{|c|}{ Characteristics } & \multicolumn{2}{c|}{ Reconstruction price } \\
\cline { 3 - 4 } & & $\begin{array}{c}\text { thous. LTL } \\
\cdot\left(1000 \mathrm{~m}^{2}\right)^{-1}\end{array}$ & $\begin{array}{c}\text { thous. EUR } \\
\cdot\left(1000 \mathrm{~m}^{2}\right)^{-1}\end{array}$ \\
\hline $\begin{array}{l}\text { Car parking } \\
\text { sites }\end{array}$ & asphalt cover (2 layers) & 151 & 44 \\
\hline Access roads & asphalt cover (2 layers) & 103 & 30 \\
\hline Pavements & $\begin{array}{l}\text { concrete cover paving } \\
\text { blocks }\end{array}$ & 158 & 46 \\
\hline Pathways & concrete cover blocks & 116 & 34 \\
\hline
\end{tabular}


\begin{tabular}{|l|l} 
Plantations & lawn, trees, bushes
\end{tabular}

Source: Sistela [2012], modified.

\section{Losses of forest production}

The present study assumes that flooding does not make any impact on forest production. This assumption is due to the fact that flood duration is not long enough to make a substantial damage on forests in Lithuania. Furthermore, freshwater swamp forests can already be found in most of the areas associated with high likelihood of flooding.

\section{Agricultural biological asset losses}

The losses of agricultural activities encompass crop farming losses and animal farming losses. An assumption is made that flood damage is caused to winter and spring plants as well as animals.

Assessment of crop production losses. Applying standard ArcGIS software functions, arable land layers (polygons) and inundated area layers (polygons) are intersected. By the means of flood hazard maps, the expected inundation depth is calculated for $10 \%, 1 \%$ and $0.1 \%$ probability flood.

The average value of crop production under risk is taken into account when estimating the associated flood risk. Crop production losses are calculated in the following way:

$$
A^{c}=C \sum_{p \in\{0.001 ; 0.01 ; 0.1\}}(p \cdot U A A(p, \varepsilon))
$$

where:

$$
\begin{aligned}
& A^{c}-\text { crop production losses, } \\
& C-\text { the average crop output value, EUR } \cdot h^{-1}, \\
& U A A-\text { Utilized Agricultural Area which depends } \\
& \quad \text { on flood characteristics, } \\
& p \quad-\text { a certain flood probability. }
\end{aligned}
$$

\begin{tabular}{|c|c|}
\hline Indicators & Data sources \\
\hline $\begin{array}{l}\text { Control land plot database } \\
\text { KŽS_DB10LT (G code bl1, } \\
\text { bl1b) (arable land polygons) } \\
\text { Layer of flood inundated } \\
\text { buildings } \\
\text { Map of residents that may be } \\
\text { affected by floods }\end{array}$ & $\begin{array}{l}\text { LR Real Estate Cadastre and LR } \\
\text { Real Estate Register data M } \\
\text { 1:10 } 000 \text { on structures } \\
\text { Lithuanian geo-reference database } \\
\text { GDB10LT/maps.lt data }\end{array}$ \\
\hline $\begin{array}{l}\text { Less favoured areas (munici- } \\
\text { palities, townships) }\end{array}$ & $\begin{array}{l}\text { Order of the Minister of Agricul- } \\
\text { ture of the Republic of Lithuania } \\
\text { "Regarding less favoured areas", } \\
\text { No. 3D-72, 27 February } 2004\end{array}$ \\
\hline Crop output value per hectare & $\begin{array}{l}\text { Farm Accountancy Data Network } \\
\text { data, Lithuanian Institute of Agrar- } \\
\text { ian Economics }\end{array}$ \\
\hline
\end{tabular}

Table 6 summarises the main data used for estimation of damage to crop farming.

Table 6. Data and their sources when calculating flood damage to crop production

Source: own elaboration.

According to Farm Accountancy Data Network data, the value of crop output in Lithuania varies by land quality. In favoured areas, according to 2011 data, it equalled $1779 \mathrm{LTL} \cdot \mathrm{ha}^{-1}\left(515 \mathrm{EUR} \cdot \mathrm{ha}^{-1}\right)$, in less favoured areas (LFA) - $1088 \mathrm{LTL} \cdot \mathrm{ha}^{-1}$. It is assumed that, irrespectively of inundation depth, the crop output is completely destroyed. Therefore, no specific damage function is introduced.

Assessment of animal farming losses. Assessment is carried out by means of map cells depicting residents that may be affected by floods (rural areas are considered with cell size of $1000 \mathrm{~m} \times 1000 \mathrm{~m}$ ). For flood inundated buildings, proportionally to the polygon area of the building, the number of residents that may be affected by flood is estimated. The number of livestock units (LU) is assumed to be uniformly distributed along the rural population within each township. These numbers are adjusted in case large concentrated animal feeding operations (CAFOs) are active within certain townships. The animal output per livestock unit is estimated in accordance with the data from the Farming Accountancy Data Network (the same value for the whole country). Table 7 summarises the data needed for calculations. The damage function is involved in the analysis (Fig. 3).

Table 7. Data for estimation of flood damage to animal farming

\begin{tabular}{|l|l|}
\hline \multicolumn{1}{|c|}{ Indicators } & \multicolumn{1}{|c|}{ Data sources } \\
\hline $\begin{array}{l}\text { Building polygons } \\
\text { Inhabitants }\end{array}$ & $\begin{array}{l}\text { LR Real Estate Cadastre and LR } \\
\text { Real Estate Register data M } \\
1: 10000 \text { on structures } \\
\text { Lithuanian geo-reference database } \\
\text { GDB10LT/maps.lt data }\end{array}$ \\
\hline $\begin{array}{l}\text { Number of rural residents in } \\
\text { townships }\end{array}$ & $\begin{array}{l}\text { Official Statistic Portal. Access via } \\
\text { internet: http://osp.stat.gov.lt/ }\end{array}$ \\
\hline $\begin{array}{l}\text { Number of animals (livestock } \\
\text { and poultry) in townships }\end{array}$ & $\begin{array}{l}\text { Official Statistic Portal. Access via } \\
\text { internet: http://osp.stat.gov.lt/ }\end{array}$ \\
\hline $\begin{array}{l}\text { Total livestock output per } \\
\text { livestock unit }\end{array}$ & $\begin{array}{l}\text { Farm Accountancy Data Network, } \\
\text { Lithuanian Institute of Agrarian } \\
\text { Economics }\end{array}$ \\
\hline $\begin{array}{l}\text { Addresses of large stockbreed- } \\
\text { ing complexes }\end{array}$ & $\begin{array}{l}\text { Lithuanian Pig Producers' Asso- } \\
\text { ciation }\end{array}$ \\
\hline $\begin{array}{l}\text { Number of animals in large } \\
\text { stockbreeding complexes }\end{array}$ & $\begin{array}{l}\text { Telephone survey of large stock- } \\
\text { breeding complexes }\end{array}$ \\
\hline
\end{tabular}

Source: own elaboration.

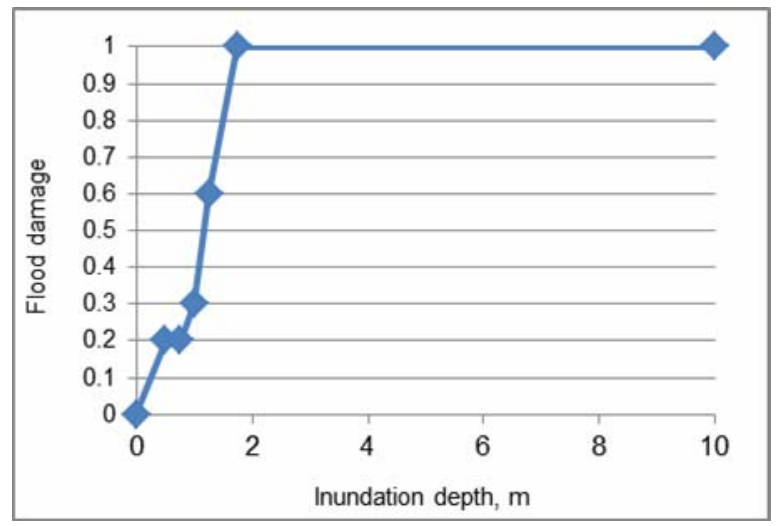

Fig. 3. Damage function for livestock; source: MEYER et al. [2011], modified

In Lithuania, producers of two types exist: smallscale farms and CAFOs. Flood damage consists of 
losses resulting from the perishing of domestic animals or flood-caused diseases. The following assumptions are used for calculations:

1. The most intensive floods occur in early spring when animals are still kept indoors, therefore losses are in direct proportion to the number of the population that may be affected by floods;

2. Losses arising from the perishing of domestic animals or flood-caused diseases are not assessed in urban areas;

3. Animal farming losses are not estimated for CAFOs. However, these entities are indicated on a risk map.

The losses arising from animal farming activities in a certain township are estimated as follows:

$$
A^{a}=L \sum_{p \in\{0.001 ; 0.01 ; 0.1\}}(p \cdot L U \cdot \operatorname{pop}(p, \varepsilon) \cdot d(h(p)))(4)
$$

where:

$$
\begin{aligned}
& A^{a} \quad \text { - livestock farming losses, } \\
& L \quad \text { - the livestock output value per LU, } \\
& L U \text { - the number of LUs per inhabitant in an }
\end{aligned}
$$

As of 2011, the value of livestock output equalled $3670 \mathrm{LTL} \cdot \mathrm{LU}^{-1}\left(1062 \mathrm{EUR} \cdot \mathrm{LU}^{-1}\right)$.

\section{Urban infrastructure reconstruction costs}

Reconstruction costs of urban infrastructure objects (pavements, pathways, greenings etc.) are based on the data sources given in Table 3. Furthermore, the same damage function is employed (Fig. 2).

Reconstruction costs of an infrastructure object are calculated in the following manner:

$$
U=C \sum_{p \in\{0.001 ; 0.01 ; 0.1\}}(p \cdot S(p, \varepsilon) \cdot d(h(p)))
$$

where:

$U$ - reconstruction cost,

$C$ - construction cost,

$S(\cdot)$ - the inundated area under urban infrastructure object,

$d(\cdot)$ - the value of a damage function,

$h(\cdot)$ - the inundation depth under a given level of probability, $p$.

\section{Losses due to interruption of economic activities}

Assessment of losses due to interruption of economic activities rests on the following assumptions:

- Gross Value Added (GVA) per employed person is calculated according to administrative territories (municipalities) and residential areas (urban and rural), i.e. GVA is distributed by the number of employed persons within the appropriate territory (municipalities, separately for urban and rural areas) and the working persons are distributed evenly within these territories;

- GVA is generated steadily throughout the year (i.e. 253 working days on average);

- Interruption of economic activities occurs both in the inundated areas and the areas delimited by inundations (islands formed) at water depth more than $10 \mathrm{~cm}$ and does not depend on inundation depth.

In order to estimate the losses due to interrupted economic activity, we need to estimate average loss of GVA per day per ha. For that, we estimated the average GVA per employee across the counties given their GVA structure (country-level data were used to derive sector specific productivity of labour). In addition, the number of employees within each municipality is divided by its area thus arriving at the indicator of labour density. The product of labour density and labour productivity then serves as a proxy for the average GVA per hectare. These estimates are obtained for rural and urban areas separately. Denoting the resulting variable as $G$, we can specify the following expression for losses due to interruption of economic activity in a certain territory (rural/urban grid cell within a municipality):

$$
E=G \sum_{p \in\{0.001 ; 0.01 ; 0.1\}}(p \cdot S(p, \varepsilon) \cdot t(p, \varepsilon))
$$

where:

$$
\begin{array}{ll}
E- & \text { loss associated with interruption of eco- } \\
& \text { nomic activity, } \\
p \quad- & \text { probability of flooding, } \\
S(\cdot)- & \text { inundated area, } \\
t(\cdot) \quad- & \text { the duration of the inundation. }
\end{array}
$$

Table 8. Data and their sources when calculating losses due to economic activity disturbance

\begin{tabular}{|l|l|}
\hline \multicolumn{1}{|c|}{ Indicators } & \multicolumn{1}{|c|}{ Data sources } \\
\hline $\begin{array}{l}\text { Number of inhabitants in the } \\
\text { inundated territories }\end{array}$ & $\begin{array}{l}\text { LR Real Estate Cadastre and LR } \\
\text { Real Estate Register data M } \\
1: 10 \text { 000 on structures } \\
\text { Lithuanian geo-reference database } \\
\text { GDB10LT/maps.lt data } \\
\text { Flood hazard map data }\end{array}$ \\
\hline $\begin{array}{l}\text { Gross Value Added (GVA) by } \\
\text { counties and types of eco- } \\
\text { nomic activities }\end{array}$ & $\begin{array}{l}\text { Official Statistic Portal. Access } \\
\text { via internet: http://osp.stat.gov.lt/ }\end{array}$ \\
\hline $\begin{array}{l}\text { Number of the employed in } \\
\text { municipalities: }\end{array}$ & $\begin{array}{l}\text { Official Statistic Portal. Access } \\
\text { via internet: http://osp.stat.gov.lt/ }\end{array}$ \\
\hline $\begin{array}{l}\text { Number of residents in mu- } \\
\text { nicipalities (urban/rural) }\end{array}$ & $\begin{array}{l}\text { Official Statistic Portal. Access } \\
\text { via internet: http://osp.stat.gov.lt/ }\end{array}$ \\
\hline $\begin{array}{l}\text { Areas of municipalities (ur- } \\
\text { ban/rural) }\end{array}$ & HNIT Baltic UAB \\
\hline
\end{tabular}

Source: own elaboration.

Indirect economic, social costs and expenses for emergency and long-term assistance measures

Since it is difficult to estimate indirect economic, social costs and expenses for emergency and long- 
term assistance measures in monetary terms, certain assumptions on the magnitude of such costs are imposed relative to the total direct costs. Considering previous research on appraisal of flood damage [JONGMAN et al. 2012; REESE, RAMSAY 2010], this percentage varies in between $10 \%$ and $25 \%$. Thus, upon having consulted experts and basing on foreign experience, the indirect costs were assumed to amount $15 \%$ of the total direct costs.

\section{RISK ASSOCIATED WITH SOCIO-POLITICAL ASPECTS}

Socio-political risk arises from flood damage upon the most vulnerable social groups of society. This kind of risk is accounted for by considering the number of inhabitants affected by a flood as well as flood hazard.

In order to estimate the number of potentially affected inhabitants, the following geographic data are used: map of residents that may be affected by floods; Maps.lt data on healthcare and education institutions; flood hazard map data.

As regards risk associated with socio-political aspects, the two types thereof are identified, namely risk of exclusion and social risk. The former issue is tackled by including such entities as healthcare and education institutions in the flood risk map.

Social risk comprises multiple dimensions. Specifically, the following indicators are used to describe the evaluation of flood risk to social aspects: 1) residents over 75 years of age, \%; 2) residents with chronic diseases or with long-term health problems, $\% ; 3$ ) average disposable monthly income per household, LTL; 4) residents younger than 15 years of age, $\%$; 5) unemployment level, \%; 6) share of individuals living in households, not possessing items of long use due to the lack of funds, \%; 7) share of individuals living in households, confronting with economic difficulties, \%; 8) useful area per capita, $\mathrm{m}^{2}$. As these indicators are expressed in different measurement units, they are therefore aggregated using a multicriteria evaluation method and after being divided into 5 groups (levels) are reflected in a map (only buildings will be marked).

Taking into account the methodical principles presented in Section 2 and considering TAPSELL et al. [2002; 2005], the indicator system has been developed for the assessment of social damage caused by flood in Lithuanian municipalities. The indicator system is presented in Table 9. Data of the Statistics Lithuania database were used.

To simplify the interpretation of results, the region most risky in terms of flood damage is considered as an optimum solution. Each indicator has a direction of optimization defined, thus the most risky region is a hypothetical (optimal) multi-criteria evaluation alternative. The statistical indicators identifying social risk are expressed in different measurement units; therefore, their aggregation is required. For this purpose, multi-criteria assessment methods may be used. In this study, the use is made of the ratio system method, proposed by BRAUERS and ZAVADSKAS

Table 9. Indicator system for the assessment of social damage caused by flood in Lithuanian municipalities

\begin{tabular}{|c|l|c|c|}
\hline No. & \multicolumn{1}{|c|}{ Indicator } & $\begin{array}{c}\text { Level of } \\
\text { aggrega- } \\
\text { tion }\end{array}$ & $\begin{array}{c}\text { Direction } \\
\text { of optimi- } \\
\text { sation }\end{array}$ \\
\hline 1. & Residents over 75 years of age, \% & $\mathrm{m}$ & $\mathrm{max}$ \\
\hline 2. & $\begin{array}{l}\text { Residents with chronic diseases or } \\
\text { with long-term health problems, \% }\end{array}$ & $\mathrm{c}$ & $\max$ \\
\hline 3. & $\begin{array}{l}\text { Average disposable monthly income } \\
\text { per household, LTL }\end{array}$ & $\mathrm{c}$ & $\min$ \\
\hline 4. & Residents younger than 15 years, \% & $\mathrm{m}$ & $\max$ \\
\hline 5. & Unemployment level, \% & $\mathrm{c}$ & $\max$ \\
\hline 6. & $\begin{array}{l}\text { Share of individuals living in house- } \\
\text { holds not possessing items of long use } \\
\text { due to the lack of funds, \% }\end{array}$ & $\mathrm{c}$ & $\max$ \\
\hline 7. & $\begin{array}{l}\text { Share of individuals living in house- } \\
\text { holds confronting with economic } \\
\text { difficulties, \%. }\end{array}$ & $\mathrm{c}$ & $\max$ \\
\hline 8. & Useful area per capita, $\mathrm{m}^{2}$ & $\mathrm{~m}$ & $\min$ \\
\hline
\end{tabular}

Explanation: level of aggregation indicates whether data are available at municipal level $(m)$ or county level $(c)$. Direction of optimisation indicates whether the region associated with the highest risk features higher $(\max )$ values or lower values $(\min )$ of a certain indicator.

Source: own elaboration.

[2006], which is similar to the simple additive weighting, even though vector normalization is used.

In the assessment of a potential social risk we have made an assumption that all criteria presented in Table 10 are of equal value (have equal weights). Data are restructured to the decision matrix $X$, where elements $x_{i j}$ denote $j$-th criterion of $i$-th alternative $(i=$ $1,2, \ldots, m$ and $\mathrm{j}=1,2, \ldots, n)$. In this case we analyze $m=8$ criteria and $n=60$ alternatives - municipalities. Data are transformed to dimensionless numbers applying vector normalization:

$$
x_{i j}^{*}=\frac{x_{i j}}{\sqrt{\sum_{i=1}^{m} x_{i j}^{2}}}
$$

where $x_{i j}{ }^{*}$-denotes normalized $j$-th criterion of $i$-th alternative. If negative values are absent, this value belongs to the interval $[0 ; 1]$.

Normalized values are added up (if criteria are maximised) and subtracted (if criteria are minimised):

$$
y_{i}^{*}=\sum_{j=1}^{g} x_{i j}^{*}-\sum_{j=g+1}^{n} x_{i j}^{*}
$$

where:

$g=1, \ldots, m-$ denotes criteria to be maximised,

$y_{i}^{*}$ - the aggregate index.

In this case, the higher values of the index indicate the higher potential social damage of the flood.

Damage index values calculated for municipalities cannot be differentiated at the township or lower levels due to the lack of data. To estimate the social risk of floods, the number of residents that may be 
affected by a flood is multiplied by the social flood damage assessment index.

\section{COMPLEX ASSESSMENT OF FLOOD RISK}

Multi-criteria evaluation models and methods are applied in integrating all types of damage. The aggregate damage index, $y_{i}$, is calculated for each grid cell. The aggregate risk index is based on 1) risk to inhabitants, 2) risk to economy and environment, and 3) risk associated with socio-political aspects. Whereas the second type of risk is measured in monetary terms (cf. Section Risk to economic activities and environment), the first and the last ones are an aggregate index themselves (cf. Section Risk associated to sociopolitical aspects). Therefore, these values need to be normalised and further aggregated into an overall index of flood risk:

$$
y_{i}=\frac{P_{i}}{\max _{i} P_{i}}+\frac{E_{i}}{\max _{i} E_{i}}+\frac{y_{i}^{*}}{\max _{i} y_{i}^{*}}
$$

where:

$P_{i}$ - the number of inhabitants,

$E_{i}$ - the sum of monetary losses described in Section Risk to economic activities and environment,

$y_{i}^{*}-$ estimated in terms of Eq. 8 .

In this particular case we assume equal importance of the components of the overall flood risk index. However, one can introduce weights in order to account for some preferences regarding different risks of flood.

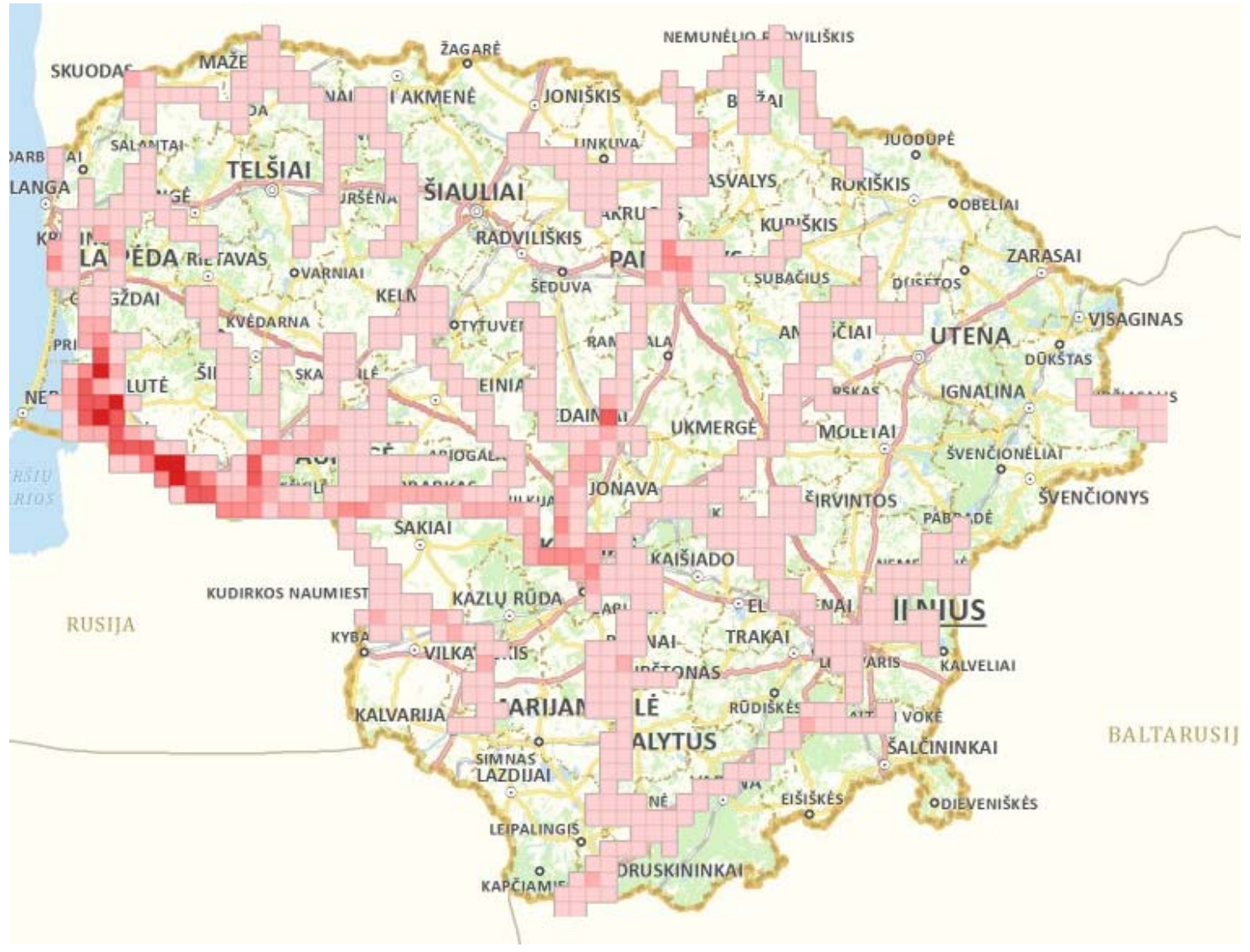

Fig. 4. The integrated flood risk map for Lithuania (fluvial and pluvial flooding); source: Environmental Protection Agency, HNIT

The resulting flood risk map for Lithuania ${ }^{1)}$ is depicted in Fig. 4. Note that the more intensive colours are associated with higher flood risk. Fig. 4 presents an integrated risk map, whereas partial risk maps are also available, yet not depicted here for the sake of brevity.

\footnotetext{
1) The interactive flood risk map based on the presented methodology is available at http://potvyniai.aplinka.lt/ potvyniai/
}

As one can note, the highest flood risk is observed in the western part of Lithuania, viz. Šilute and Taurage districts. The risk of moderate level has been estimated for Kèdainiai and Panevėžys. Some risky areas are also found in Kaunas district. Therefore, flood risk management is crucial for western and central Lithuania, whereas other parts of the country are not likely to suffer from significant losses due to flooding. 


\section{CONCLUSIONS}

In this paper, we have proposed an integrated methodology for flood risk assessment. The overall flood risk is estimated in terms of risk to inhabitants, risk to economic activities, and risk to social security. The proposed methodology encompasses models for flood hazard estimation, flood damage functions, and multi-criteria techniques for aggregation of the results.

The constructed flood risk maps enabled to identify the most vulnerable areas across Lithuania. The results indicate that flood risk management is crucial for western and central Lithuania, whereas other parts of the country are not likely to suffer from significant losses due to flooding.

The future research could focus on application of advanced damage functions, for instance stage-veloci-

ty-depth functions [MIDDELMANN-FERNANDES 2010].

In addition, the resolution of the flood risk maps might be increased in case more detailed data are available. Furthermore, other multi-criteria techniques might be applied for aggregation.

\section{REFERENCES}

BRAUERS W., ZAVADSKAS E.K. 2006. The MOORA method and its application to privatization in a transition economy. Control and Cybernetics. No. 35(2) p. 445-469.

Directive 2007/60/EC of the European Parliament and of the council of 23 October 2007 on the assessment and management of flood risks. OJ L 288/27.

EEA 2012. Climate change, impacts and vulnerability in Europe. EEA Report. No. 12/2012. ISBN 978-92-9213346-7 pp. 300.

GouldBy B., SAMUEls P. 2005. Language of risk. Project definitions. Report T32-04-01 [online]. [Access 01.06.2015]. Available at: http://www.adbarno.it/rep/ biblio/FLOODsite Language of Risk v4 0 P1.pdf

HARTMANN T., AlBrECHT J. 2014. From flood protection to flood risk management: Condition-based and performance-based regulations in German water law. Journal of Environmental Law. No. 26. Iss. 2 p. 243-268.

Jongman B., Kreibich H., Apel H., Barredo J.I., Bates P.D., Feyen L., Gericke A., Neal J., Aerts J.C.J.H., WARD P.J. 2012. Comparative Flood Damage Model Assessment: Towards a European Approach. Natural Hazards and Earth System Sciences. No. 12 p. $3733-$ 3752.

JoNKMAN S.N., BoČKARJOVA M., KOK M., BERnARDINI P. 2008. Integrated hydrodynamic and economic model- ling of flood damage in the Netherlands. Ecological Economics. Vol. 66. Iss. 1 p. 77-90.

Messner F., Penning-Rowsell E., Green C., Meyer V., Tunstall S., VAN DER VEEN A. 2007. Evaluating flood damages: guidance and recommendations on principles and methods. Wallingford, UK. FLOODsite Consortium pp. 178.

Meyer V., Kuhlicke C., Luther J., Unnerstall H., Fuchs S., Priest S., Pardoe J., McCarthy S., DorNer W., Seidel J., Serrhini K., Palka G., Scheuer S. 2011. Risk map. Improving flood risk maps as a means to foster public participation and raising flood risk awareness: Toward flood resilient communities [online]. CRUE Final Report. [Access 01.06.2015]. Available at: http://risk-map.org/outcomes/CRUE_RiskMap_Final Report final.pdf

MidDELmann-Fernandes M.H. 2010. Flood damage esti-

mation beyond stage-damage functions: an Australian example. Journal of Flood Risk Management. Vol. 3. Iss. 1 p. 88-96.

Moel H.D., AlPhen J.V., AerTs J.C.J.H. 2009. Flood maps in Europe - methods, availability and use. Natural Hazards and Earth System Science. No 9 p. 289-301.

OuMA Y.O., TATEISHI R. 2014. Urban flood vulnerability and risk mapping using integrated multi-parametric AHP and GIS: Methodological overview and case study assessment. Water. Vol. 6. Iss. 6 p. 1515-1545.

REESE S., RAMSAY D. 2010. RiskScape: Flood fragility methodology. Wellington, New Zealand. National Institute of Water and Atmospheric Research pp. 42.

Sistela 2012. Nekilnojamojo turto atkūrimo kaštų kainynas [Directory of the Real Estate Replacement Costs] NTK 2012. Vilnius.

Tapsell S., Tunstall S., Green C., Fernandez-Bilbao A. 2005. Task 11. Social indicator set. Integrated Flood Risk Analysis and Management Methodologies. Wallingford, UK. FLOODsite Consortium pp. 32.

Tapsell S.M., Penning-Rowsell E.C., Tunstall S.M., WILSON T.L. 2002. Vulnerability to flooding: health and social dimensions. Philosophical Transactions of the Royal Society of London A: Mathematical, Physical and Engineering Sciences. Vol. 360. Iss. 1796 p. 15111525.

VAN DER SANDE C.J., DE JONG S.M., DE RoO A.P.J. 2003. A segmentation and classification approach of IKONOS-2 imagery for land cover mapping to assist flood risk and flood damage assessment. International Journal of Applied Earth Observation and Geoinformation. Vol. 4. Iss. 3 p. $217-229$.

Webster T., McGuigan K., Collins K., MacDonald C. 2014. Integrated river and coastal hydrodynamic flood risk mapping of the LaHave River Estuary and town of Bridgewater, Nova Scotia, Canada. Water. Vol. 6. Iss. 3 p. $517-546$. 


\section{Irena KRIŠČIUKAITIENĖ, Tomas BALEŽENTIS, Aistė GALNAITYTE், Virginia NAMIOTKO}

\section{Metodologia oceny zagrożenia powodziowego na Litwie}

\section{STRESZCZENIE}

W artykule przedstawiono metodologię mapowania ryzyka powodziowego zgodnie z zaleceniami Dyrektywy 2007/60/EC w sprawie oceny ryzyka powodziowego i zarządzania nim. Celem Autorów było w szczególności zidentyfikowanie typów szkód powodziowych, które można oszacować pod warunkiem dostępności danych na Litwie. Ponadto przedstawiono główne źródła danych i powiązane funkcje kosztów. Metodologia obejmuje następujące główne typy zagrożeń powodziowych: zagrożenia dla mieszkańców, zagrożenia dla działalności gospodarczej i zagrożenia społeczne. Zaproponowano wielokryterialne ramy do powiązania różnych rodzajów zagrożeń celem zapewnienia całościowej oceny ryzyka powodziowego. Na podstawie proponowanych badań sporządzono mapy zagrożenia powodziowego dla Litwy. Mapy te są dostępne dla każdego typu zagrożeń (tzn. mieszkańców, gospodarki i zagrożeń społecznych) i dla łącznego ryzyka. Wyniki dowodzą, że zarządzanie ryzykiem powodziowym ma zasadnicze znaczenie dla zachodniej i centralnej Litwy, inne obszary kraju nie powinny doznać istotnych strat w wyniku powodzi.

Słowa kluczowe: Litwa, mapa powodzi, prawdopodobieństwo powodzi, ryzyko powodziowe 